\title{
Michel Murat, Le Coup de dés de Mallarmé
}

\section{Ida Merello}

\section{(2) OpenEdition}

\section{Journals}

\section{Edizione digitale}

URL: http://journals.openedition.org/studifrancesi/33498

DOI: 10.4000/studifrancesi.33498

ISSN: 2427-5856

\section{Editore}

Rosenberg \& Sellier

\section{Edizione cartacea}

Data di pubblicazione: 1 décembre 2005

Paginazione: 668

ISSN: 0039-2944

\section{Notizia bibliografica digitale}

Ida Merello, «Michel Murat, Le Coup de dés de Mallarmé», Studi Francesi [Online], 147 (XLX | III) | 2005,

online dal 30 novembre 2015, consultato il 20 avril 2021. URL: http://journals.openedition.org/

studifrancesi/33498 ; DOI: https://doi.org/10.4000/studifrancesi.33498

\section{Questo documento è stato generato automaticamente il 20 avril 2021.}

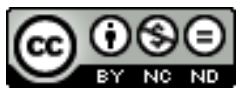

Studi Francesi è distribuita con Licenza Creative Commons Attribuzione - Non commerciale - Non opere derivate 4.0 Internazionale. 


\title{
Michel Murat, Le Coup de dés de Mallarmé
}

\author{
Ida Merello
}

\section{NOTIZIA}

MiCHel MURAT, Le Coup de dés de Mallarmé, Tours, Belin 2005, pp. 181.

1 Nella collana dell'extrême contemporain curata da Michel Déguy, ecco questo libro «incontournable» di Michel Murat, che propone una lettura analitica e attenta del Coup de dés dopo un'ampia disamina delle concezioni mallarmeane del verso e delle innovazioni metriche. Il grande pregio dell'A. è proprio quello di inserire l'opera in un prospettiva storica, tenendo presente sia l'anno della sua pubblicazione, 1914, che la fa entrare nelle dinamiche della poesia d'avanguardia, sia il rapporto con l'evoluzione delle teorie di Mallarmé nei confronti di versificazione tradizionale e verso libero. Per l'A. infatti è molto importante sottolineare come le riflessioni del poeta in proposito sino contraddittorie, in quanto prolungate nel tempo, e non organizzate in unico sistema. Tutta la seconda parte del volume è dedicata al coup de dés, di cui l'A. confronta la prima pubblicazione in rivista, su pagina semplice, con il testo a pagina doppia originariamente concepito. L'A. è interessato comunque al prodotto finito, perciò trascura volutamente i brouillons, richiamandosi soltanto per la sua analisi agli studi precedenti, in special modo all'edizione Pléiade di Marchal. Il saggio ha un apprezzabile carattere di concretezza e ogni affermazione riposa sullo scandaglio attento dei dati. L'esame del corpus delle affermazioni teoriche di Mallarmé permette di proporre tutte le definizioni di verso e di rima che il poeta ha concepito; analogamente sono esaminati gli esempi di autori verslibristi citati da Mallarmé, mentre il Coup de dés è osservato da tutti i possibili punti di vista, dagli aspetti metrici, ritmici, visivi, a quelli sintattici e musicali, della lettura orale e del contenuto. 